\title{
Impact of Chlorpyrifos on Plant Growth Promoting Rhizobacteria Isolated from Abelmoschus esculentus
}

\author{
Preeti Swarupa and Anil Kumar* \\ Department of Life Sciences, School of Natural Sciences, Central University of Jharkhand, \\ Brambe, Ranchi - 835 205, Jharkhand, India.
}

\begin{abstract}
Chlorpyrifos (CP), an organophosphate insecticide, is massively used in agriculture for protecting cereal and vegetable crops from various types of pests. Its persistence and toxic nature towards non-target organisms has ensued in widespread contamination causing noxious effect on terrestrial and aquatic living entities including humans. Change in soil microflora biodiversity due to excessive CP use is a major concern nowadays as it will affect soil fertility ultimately leading to detrimental effect on plant health and yield. In the present study impact of CP on PGPRs from Okra (Abelmoschus esculentus) plant has been tested. Three bacterial isolates 0-1, 0-2 and 0-3 were isolated, all showing either or combinations of selected plant growth promoting characters such as nitrogen fixation, phosphate solubilisation, IAA production and siderophore production. 0-2 isolate was showing all the four selected plant growth promoting traits. Effects of CP (RADAR $20^{\circ} \mathrm{EC}$ ) on growth of three isolates were checked on Luria Bertani (LB) agar and M9 minimal medium (M9MM) salts supplemented with CP (50, 500 and $5000 \mathrm{mg} / \mathrm{L})$. 0-1 and 0-2 grew on LB agar and M9MM agar media supplemented with 50,500 and $5000 \mathrm{mg} / \mathrm{L} \mathrm{CP}$ revealing their tolerance to CP. O-2 isolate after repeated field trial and biodegradation study, can prove as potential candidate for PGPR possessing potential of bioremediation of pesticide (chlorpyrifos) contamination as well.
\end{abstract}

Keywords: Chlorpyrifos, organophosphate, microflora, PGPR, tolerance.

*Correspondence: anil.kumar@cuj.ac.in; kumaranilvp@rediffmail.com; +91-9955273226

(Received: 15 September 2018; accepted: 06 November 2018)

Citation: Preeti Swarupa and Anil Kumar; Impact of chlorpyrifos on plant growth promoting rhizobacteria isolated from Abelmoschus esculentus, J Pure Appl Microbiol., 2018; 12(4):2149-2157. http://dx.doi.org/10.22207/JPAM.12.4.53

(c) The Author(s) 2018. Open Access. This article is distributed under the terms of the Creative Commons Attribution 4.0 International License which permits unrestricted use, sharing, distribution, and reproduction in any medium, provided you give appropriate credit to the original author(s) and the source, provide a link to the Creative Commons license, and indicate if changes were made. 


\section{INTRODUCTION}

Soil is teeming with diverse group of microorganisms for example bacteria, fungi, actinomycetes, algae, nematodes etc. Among the various categories of microorganism, bacteria plays promising role by influencing different biotic factors of soil ecosystem like taking part in nutrient recycling and enhancement of plant growth and yield, formation of soil structure, bioremediation and biodegradation of toxic xenobiotics and heavy metals ${ }^{1,2,3,4,5,6}$. Plant growth promoting rhizobacteria (PGPR) hold a major position because these belongs to the group of root colonizing beneficial bacteria which enhances plant growth through various mechanisms such as acquisition and solubilisation of unavailable nutrients like nitrogen, phosphates, iron and production of plant hormones like IAA, gibberallins and cytokinins and acting as biocontrol agents and replaces explicit use of fertilizers and pesticides ${ }^{7,8,9}$. In addition farmers are obligated to use chemical means in the form of fertilizers, pesticides, herbicide etc. to increase the agricultural productivity to fulfil economic need and food security ${ }^{10,11}$. Pesticides (insecticide, nematicide, herbicide, fungicide) are a group of chemical compounds which are applied in agriculture fields to combat damage of crops, vegetables and fruit plants from pests. $80 \%$ of pesticides are used in the form of insecticide in India ${ }^{12}$. Injudicious use of pesticide has created turbulences in ecological balance of hydrosphere and lithosphere. Chlorpyrifos (CP) is a type of insecticide, acaricide and nematicide belonging to the class of organophosphate which is chemically 0,0-diethyl 0-(3,5,6-trichloro-2pyridyl phosphorothioate). Dow chemicals, USA first introduced CP in 1965 for controlling insect pests in agricultural and domestic practises ${ }^{13}$. Commercially, it is available as Dursban, Lorsban, Agromil, Dorson, Dhanwan, Omexan across the world. CP has a wide application against an array of insect pests of economically valued crops. Its extravagant use and neurotoxic as well as immunotoxic nature has created a number of unavoidable and inevitable contamination of aquatic and terrestrial ecosystem causing serious threats to non-targeted organisms $\mathrm{s}^{14,15,16,17}$. CP usage disturbs microflora of soil ${ }^{18,19,20}$. Loss of microbial diversity in soil ultimately leads to loss in soil fertility which is detrimental to plant growth and productivity.

In view of above problem, the present study has investigated the isolation of PGPR which may enhance not only the plant growth but also tolerate or degrade superfluous pesticide CP.

\section{MATERIALS AND METHODS}

\section{Sample collection and isolation of bacteria}

Standing plant of Okra ( 35 days old, days were counted from planting of nursery plant into well puddled arable crop field) was aseptically collected on 25/08/2015 from agricultural field of Brambe, Ranchi, Jharkhand, India and brought to laboratory for sample processing and isolation of bacteria. Bacteria were isolated and purified in LB agar (HiMedia Laboratories Pvt. Ltd., India) media using standard pure culture techniques such as serial dilution, spread plate and streak plate ${ }^{21}$. Bacteria were assigned isolate names with an initial alphabet of source plant followed by Arabic numeral on the basis of colony, form, margin, colour, size, opacity, elevation and texture.

\section{Morphological and biochemical characterization} of bacterial isolates

The morphological and biochemical characterization of all the bacterial isolates were done by Gram staining, bacterial motility test, catalase test, citrate utilization test and Methyl Red-Voges Proskauer (MR-VP) test and nitrate reduction test ${ }^{22}$.

\section{In-vitro screening of plant growth promoting characters}

Isolated bacteria were grown overnight in $10 \mathrm{ml}$ LB broth (HiMedia Laboratories Pvt. Ltd., India) in culture tube. Cells were harvested by centrifugation (Mikro 200R, hettich, Zentrifugen, Andreas Hettich GmbH \& Co. KG, Tuttlingen, Germany) at 10,000 rpm for 5 minutes at room temperature. Cells were washed in $1 \mathrm{ml}$ normal saline and centrifuged at 10,000 rpm for 5 minutes. Cells were re-suspended in normal saline up to optical density (OD)-1 at $\lambda_{600}$. These cells were used for test of nitrogen fixation, phosphate solubilisation, indole acetic acid production and siderophore production.

\section{Nitrogen fixation test}

Nitrogen fixation by bacteria was tested by their ability to grow on nitrogen deficient 
(except atmospheric $\mathrm{N}_{2}$ ) nutrient media-JNFb (malic acid- $5 \mathrm{~g} / \mathrm{L}, \mathrm{K}_{2} \mathrm{HPO}_{4}-0.6 \mathrm{~g} / \mathrm{L}, \mathrm{KH}_{2} \mathrm{PO}_{4}-1.8 \mathrm{~g} / \mathrm{L}$, $\mathrm{MgSO}_{4} .7 \mathrm{H}_{2} \mathrm{O}-0.2 \mathrm{~g} / \mathrm{L}, \mathrm{NaCl}-0.1 \mathrm{~g} / \mathrm{L}, \mathrm{CaCl}_{2} \cdot \mathrm{H}_{2} \mathrm{O}-0.2$ $\mathrm{g} / \mathrm{L}, 1.4 \% \mathrm{Fe}-\mathrm{EDTA}-4.0 \mathrm{ml} / \mathrm{L}, \mathrm{Na}_{2} \mathrm{MoO}_{4} .2 \mathrm{H}_{2} \mathrm{O}-0.002$ $\mathrm{g} / \mathrm{L}$, bromothymol blue- $5 \mathrm{ml}(0.5 \%$ in $0.2 \mathrm{~N} \mathrm{KOH}) / \mathrm{L}$, and $\mathrm{KOH}-4.5 \mathrm{~g} / \mathrm{L}, \mathrm{pH} 5.8$ ) and their ability to change $\mathrm{pH}$ (as indication of ammonia production) of media ${ }^{23} .5 \mu \mathrm{l}$ of each culture, suspended in normal saline, was drop inoculated on JNFb agar plates and incubated (Orbital Incubator Shaker, Optics Technology, Delhi, India) at $37^{\circ} \mathrm{C}$ for 48 hours. Growth in nitrogen deficient medium followed by change in colour of medium from lightyellow to blue was recorded as positive indication of nitrogen fixation.

\section{Phosphate solubilisation}

Phosphate solubilisation character of bacteria was tested in Pikovskaya's medium (HiMedia Laboratories Pvt. Ltd., India). $5 \mu \mathrm{l}$ of each culture, suspended in normal saline, was inoculated on Pikovskayas agar medium followed by inoculum drying and incubation at $37^{\circ} \mathrm{C}$ for 48 hours. Formation of clear halo zone around the colony was observed and regarded as phosphate solubilization potential of respective bacteria.

\section{Indole acetic acid production}

Production of indole acetic acid (IAA) by bacteria was tested by method adopted from Gordon and Weber $1951^{24}$. Bacterial cultures were inoculated in JNFb broth supplemented with ammonium chloride $\left(\mathrm{NH}_{4} \mathrm{Cl}\right)$ as nitrogen source in two sets with and without tryptophan $(0.1 \mathrm{mg} / \mathrm{ml})$. Cultures were incubated at $37^{\circ} \mathrm{C}$ for 108 hours. $2 \mathrm{ml}$ samples, from each tube, were harvested aseptically at 36, 72 and 108 hours following inoculation. Samples were centrifuged at 8000 rpm. $2.0 \mathrm{ml}$ of modified Salkowski reagent ( $2 \%$ of $0.5 \mathrm{M} \mathrm{FeCl}_{3}$ in $35 \% \mathrm{HClO}_{4}$ solution) was added to $1.0 \mathrm{ml}$ of culture supernatants and incubated at room temperature for 25 minutes. Development of pink colour was regarded as positive test for IAA. Siderophore assay

Siderophore production by bacteria was done on CAS (Chrome Azurol S) agar plate as per the method of Schwyne and Neilands $1987^{25}$. CAS agar plate was prepared by mixing $50 \mathrm{ml}$ of Chrome Azurol S (60.5 mg/50 ml in water), $40 \mathrm{ml}$ of Hexadecylmethyl ammonium bromide (72.9 $\mathrm{mg} / 40 \mathrm{ml}$ in water) and $10 \mathrm{ml} \mathrm{FeCl}_{3} \cdot 6 \mathrm{H}_{2} \mathrm{O}(1 \mathrm{mM}$ in $10 \mathrm{mM} \mathrm{HCl}$ ). The volume of this final solution was made to $1000 \mathrm{ml}$ by adding King's Medium B Base (HiMedia Laboratories Pvt. Ltd., India). $5 \mu$ l of each culture, suspended in phosphate buffer, was drop inoculated on CAS agar plate and incubated at $37^{\circ} \mathrm{C}$ for 72 hours. Formation of orange halozone around the bacterial colony was regarded as positive for siderophore production test of bacterial isolates. Screening of impact of chlorpyrifos (RADAR $20^{\circ}$ EC) on PGPR isolates

Commercial grade CP (RADAR $20^{\circ}$ EC) was bought from Dharti Dhan, Lalpur, Ranchi, Jharkhand, India and used in this study. Concentration of chlorpyrifos in RADAR $20^{\circ} \mathrm{EC}$ was calculated as $192.3 \mathrm{mg} / \mathrm{L}$ and considered as stock solution which was sterilized by membrane filtration $(0.45 \mathrm{~mm})$ as per the method adopted from Chen et al., 2012 ${ }^{26}$. Effect of CP (RADAR $20^{\circ}$ $\mathrm{EC})$ on growth of bacterial isolates were checked on LB agar and M9 minimal medium (M9MM) salts (HiMedia Laboratories Pvt. Ltd., India) supplemented with three concentration $(50,500$ and $5000 \mathrm{mg} / \mathrm{L}$ ) of CP (RADAR $20^{\circ} \mathrm{EC}$ ). Isolates were grown in $10 \mathrm{ml}$ LB broth and incubated overnight. Cultures were centrifuged and washed twice with M9MM broth. $5 \mu$ l of inoculum, OD-1 at $\lambda_{600}$ was taken and spot inoculated on $L B+C P$ $(50 \mathrm{mg} / \mathrm{L}), \mathrm{LB}+\mathrm{CP}(500 \mathrm{mg} / \mathrm{L}), \mathrm{LB}+\mathrm{CP}(5000 \mathrm{mg} / \mathrm{L})$ and on $\mathrm{M} 9 \mathrm{MM}+\mathrm{CP}(50 \mathrm{mg} / \mathrm{L}), \mathrm{M} 9 \mathrm{MM}+\mathrm{CP}(500$ $\mathrm{mg} / \mathrm{L}), \mathrm{M} 9 \mathrm{MM}+\mathrm{CP}(5000 \mathrm{mg} / \mathrm{L})$ alongwith control plate of LB agar and M9MM prepared without chlorpyrifos. Observation was noted after 72 hours of incubation.

\section{Growth of bacterial isolate on analytical standard chlorpyrifos PESTANAL ${ }^{\oplus}$}

As per the method adopted from Chen et al., 2012 ${ }^{26}$, stock solution of CP PESTANAL ${ }^{\circ}$, analytical standard (Sigma Aldrich, USA) of 100 $\mathrm{g} / \mathrm{L}$ was prepared in methanol and sterilized by membrane filteration $(0.45 \mathrm{~mm})$. Bacterial isolate was grown in $10 \mathrm{ml} \mathrm{LB}$ broth and incubated overnight. Cultures were centrifuged and washed twice with M9MM broth. $5 \mu$ of inoculum, OD-1 at $\lambda_{600}$ was spot inoculated on M9MM agar media plates supplemented with three different concentration of CP PESTANAL ${ }^{\circ}$, analytical standard i.e. $50 \mathrm{mg} / \mathrm{L}, 500 \mathrm{mg} / \mathrm{L}$ and $1000 \mathrm{mg} / \mathrm{L}$ along with control plate prepared without CP. $10 \mu \mathrm{l}$ of washed culture was inoculated in M9MM broth with and without $\mathrm{CP}$ of $50 \mathrm{mg} / \mathrm{L}$ concentration and growth was measured qualitatively (turbidity) and 
quantitatively by OD at $\lambda_{600}$.

Growth response of bacterial isolates on different concentrations of salt

LB agar was reconstituted in different concentration $(0 \%, 1 \%, 2 \%, 3 \%, 4 \%, 5 \%, 6 \%$, $7 \%$ and $8 \%$ ) of sodium chloride $(\mathrm{NaCl})$. Bacterial isolate $\mathrm{O}-2$ was inoculated in $10 \mathrm{ml} \mathrm{LB}$ broth and incubated overnight at $37^{\circ} \mathrm{C}$ with shaking at 150 RPM. Cultures were washed twice with LB broth (without $\mathrm{NaCl}$ ) and suspended in LB broth (without $\mathrm{NaCl})$ at culture OD-1 at $\lambda_{600} .5 \mu \mathrm{l}$ of bacterial culture was inoculated in reconstituted LB agar plates of different concentration of $\mathrm{NaCl}$. Plates were incubated at $37^{\circ} \mathrm{C}$ and growth was recorded at 24 hours of incubation.

\section{Growth response of bacterial isolates at different} $\mathrm{pH}$

LB agar was reconstituted in sodium phosphate buffer of different $\mathrm{pH}$ range $5.8,6.0$, $6.2,6.4,6.6,6.8,7.0,7.2,7.4,7.6,7.8,8.0^{27}$. 0-2 isolate was inoculated in $10 \mathrm{ml}$ LB broth and incubated overnight at $37^{\circ} \mathrm{C}$ with shaking at 150 $\mathrm{rpm}$. Culture was washed twice and resuspended in normal saline maintaining OD- 1 at $\lambda_{600} .5 \mu \mathrm{l}$ of culture was drop inoculated in reconstituted LB agar plates of different $\mathrm{pH}$. Plates were incubated at $37^{\circ} \mathrm{C}$ and growth was recorded at 24 hours of incubation.

\section{RESULTS}

Three bacterial isolates were purified from root surface of Okra plant and were named 0-1, 0-2 and 0-3 based on colony morphology. Isolates were further confirmed and characterized on the basis of Gram's staining, motility in semisolid LB agar medium, catalase, citrate utilization, nitrate reduction and MRVP tests (Table 1).

Three isolates, subjected to test, showed

Table 1. Colony morphology and biochemical characters of isolated bacteria

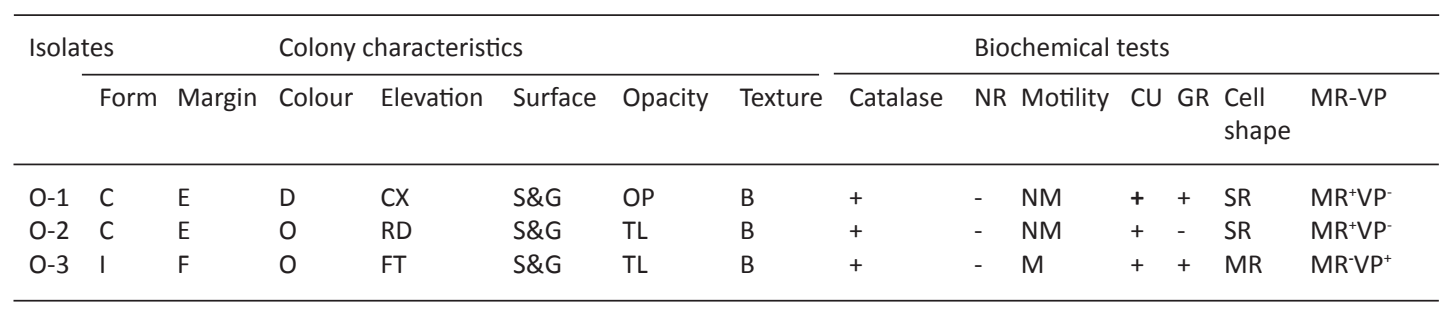

$(+)=$ positive results, $(-)=$ negative results, C-Circular, I-Irregular, E-Entire, F-Filiform, D- Dirty yellow, O- Off white, CX-Convex, RD- Raised, FT- Flat, S\&G- Smooth and glistening, OP-Opaque, TL-Translucent, B- Butyrous, NM-Non-motile, M-Motile, SRShort rods, MR- Medium Rods NR-Nitrate reduction test, GR-Gram reaction CU-Citrate utilization test, MR -VP- Methyl red -Voges Proskauer test

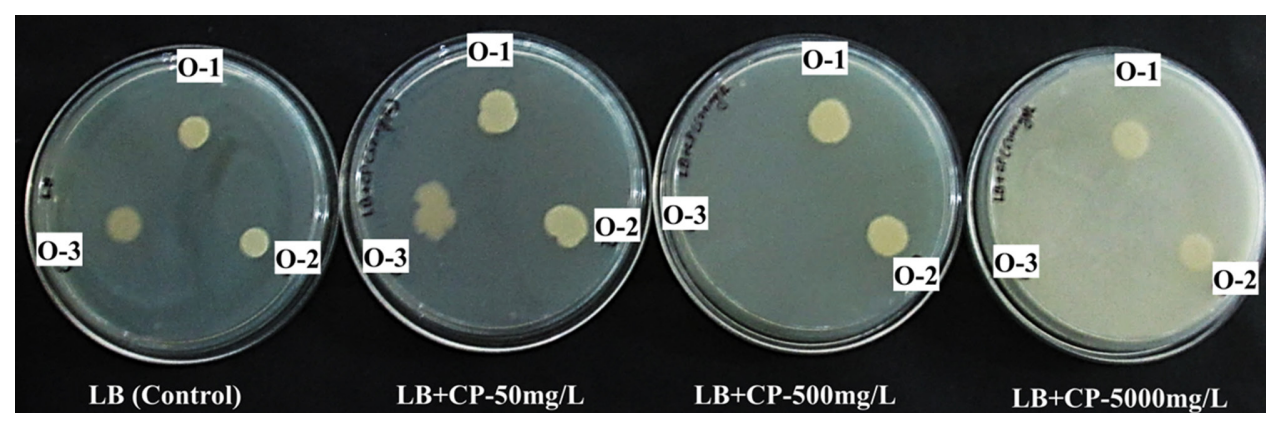

Fig. 1. Growth of $0-1,0-2$ and $0-3$ on LB agar media supplemented with different concentration of CP along with controll without $\mathrm{CP}$ 
different plant growth promoting activity such as nitrogen fixation, phosphate solubilization, IAA production and siderophore production (Table 2). One isolate i.e. O-2 was found to show all the four properties of plant growth promotion i.e. nitrogen fixation, phosphate solubilization, IAA production and siderophore production.

Growth of all the three isolates i.e.

Table 2. Result for in-vitro plant growth promoting activity

\begin{tabular}{ccccc}
\hline \multirow{2}{*}{ Isolates } & \multicolumn{4}{c}{ Tests } \\
\cline { 2 - 5 } & $\begin{array}{c}\text { Phosphate } \\
\text { solubilization }\end{array}$ & $\begin{array}{c}\text { Nitrogen } \\
\text { Fixation }\end{array}$ & $\begin{array}{c}\text { Siderophore } \\
\text { production }\end{array}$ & $\begin{array}{c}\text { IAA } \\
\text { production }\end{array}$ \\
\hline $0-1$ & $\mathrm{PS}^{+}$ & $\mathrm{NF}^{+}$ & $\mathrm{SP}^{-}$ & $\mathrm{IP}^{+}$ \\
$0-2$ & $\mathrm{PS}^{+}$ & $\mathrm{NF}^{+}$ & $\mathrm{SP}^{+}$ & $\mathrm{IP}^{+}$ \\
$0-3$ & $\mathrm{PS}^{-}$ & $\mathrm{NF}^{+}$ & $\mathrm{SP}^{-}$ & $\mathrm{IP}^{-}$ \\
\hline
\end{tabular}

$\mathrm{PS}^{+}-$Phosphate solubilization positive, $\mathrm{PS}-$-Phosphate solubilization negative, $\mathrm{NF}^{+}$-Nitrogenfixation positive, $\mathrm{SP}^{+}-$Siderophore production positive, SP--Siderophore production negative, IP+-IAA production positive, IP--IAA production negative

0-1, 0-2 and 0-3 was observed on LB agar supplemented with different concentration of CP i.e. 50, 500, $5000 \mathrm{mg} / \mathrm{L}$ (Figure 1) except O-3 isolate which showed growth only on $50 \mathrm{mg} / \mathrm{L}$ (Fig. 1, Table 3).
O-1 and 0-2 grew on the given concentration $(50,500,5000 \mathrm{mg} / \mathrm{L})$ of $\mathrm{CP}$ in M9MM agar plates but $0-3$ did not grow on any of the M9MM agar plates containing CP (Figure 2, Table 3).

Table 3. Bacterial growth on LB agar and M9MM agar media having different concentration of CP following 72 hours of incubation

\begin{tabular}{lcccccccc}
\hline Isolates & $\mathrm{LB}$ & $\mathrm{M} 9 \mathrm{MM}$ & $\begin{array}{c}\mathrm{LB}+\mathrm{CP} \\
(50 \mathrm{mg} / \mathrm{L})\end{array}$ & $\begin{array}{c}\mathrm{M} 9 \mathrm{MM}+\mathrm{CP} \\
(50 \mathrm{mg} / \mathrm{L})\end{array}$ & $\begin{array}{c}\mathrm{LB}+\mathrm{CP} \\
(500 \mathrm{mg} / \mathrm{L})\end{array}$ & $\begin{array}{c}\mathrm{M} 9 \mathrm{MM}+\mathrm{CP} \\
(500 \mathrm{mg} / \mathrm{L})\end{array}$ & $\begin{array}{c}\mathrm{LB}+\mathrm{CP} \\
(5000 \mathrm{mg} / \mathrm{L})\end{array}$ & $\begin{array}{c}\mathrm{M} 9 \mathrm{MM}+\mathrm{CP} \\
(5000 \mathrm{mg} / \mathrm{L})\end{array}$ \\
\hline $\mathrm{O}-1$ & +++ & + & +++ & + & +++ & + & +++ & + \\
$0-2$ & +++ & + & +++ & + & +++ & + & +++ & + \\
$0-3$ & +++ & - & +++ & - & - & - & - & - \\
\hline
\end{tabular}

$(+)=$ presence of growth, $(-)=$ no growth

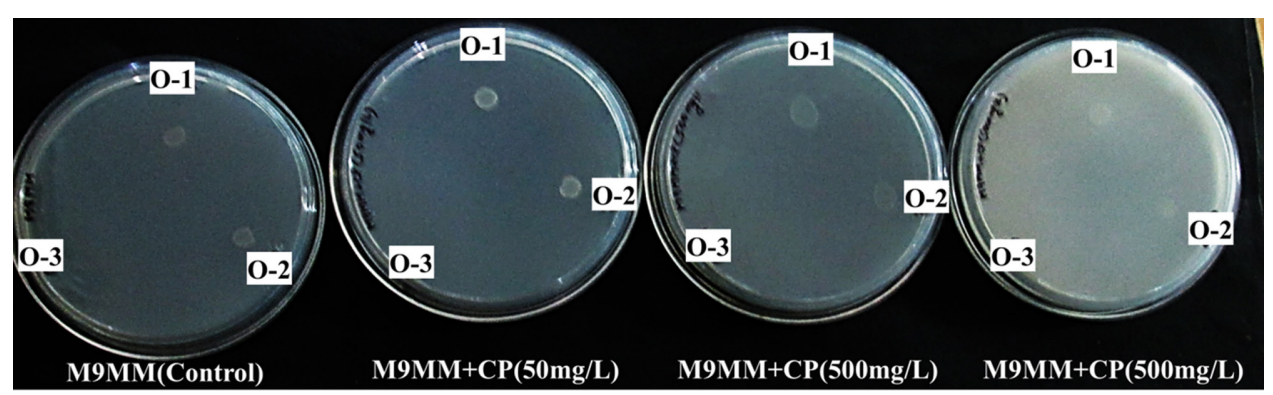

Fig. 2. Growth of O-1, O-2 and O-3 on M9MM agar media supplemented with different concentration of $\mathrm{CP}$ along with controll without $\mathrm{CP}$ 
O-2 was selected for study its growth in CP PESTANAL ${ }^{\circ}$, analytical standard as it was exhibiting all the selected plant growth promoting characters. Growth of O-2 isolate was detected on three different concentration of CP PESTANAL, analytical standard i.e. $50 \mathrm{mg} / \mathrm{L}, 500 \mathrm{mg} / \mathrm{L}$ and $1000 \mathrm{mg} / \mathrm{L}$. Growth of O-2 isolate in M9MM broth with and without $\mathrm{CP}$ reveals there was more turbidity i.e. growth observed in M9MM broth containing CP as compared to M9MM broth without CP which is also apparent from OD (Table 4).

$0-2$ isolate were found to grow in a $\mathrm{pH}$ range of $6.6-8.0$ and salinity $0.0-6 \% \mathrm{NaCl}$ though the growth was slightly inhibited at $\mathrm{pH}$ below 6.6 and higher salt concentration beyond $6 \% \mathrm{NaCl}$ (Figure 3).

Table 4. Growth of O-2 isolate on M9MM broth supplemented with and without CP PESTANAL ${ }^{\circ}$ analytical standard

\begin{tabular}{ccccc}
\hline DAY & SET & Control & Visual turbidity of isolate & OD of isolates ${ }^{\mathrm{a}, \mathrm{b}}$ \\
\hline Day 7 & SET A & - & ++ & 0.101 \\
& SET B & - & +++ & 0.144 \\
\hline
\end{tabular}

SET A - M9MM, SET B -M9MM+CP (50 mg/L), (+) = presence of growth, $(-)$ = no growth, control - without inoculation. ${ }^{a}$ OD was recorded following 7 days of incubation. ${ }^{b}$ water was taken as blank, OD in the table corresponds to corrected OD value (subtracting OD of control from all sample and control OD values). Value of control over blank (water) is 0.001 of control SET A and 0.007 of control SET B.

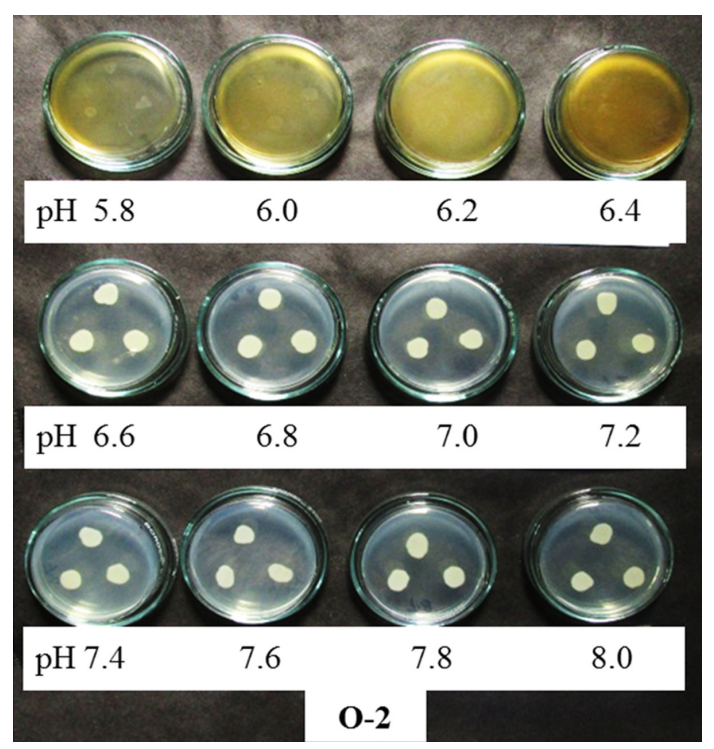

Fig. 3. Growth of $\mathrm{O}-2$ at different $\mathrm{pH}$

\section{DISCUSSION}

Reclamation of pesticide contamination through the use of biodegradation ability of microorganisms is crucial and indispensible approach for environmental clean-up in current scenario. Use of PGPR strains for biodegradation of pesticide will be one of the greatest strategies to be adopted not only for decontamination of pesticide but also restricting the use of fertilizers which is vastly used for plant growth. In the present study, three different bacterial isolates were isolated from root surface of $A$. esculentus and found to be having one or more of the selected plant growth promoting characters i.e. nitrogen fixation, phosphate solubilisation, IAA production and siderophore production. Occurrence of huge number of plant growth promoting bacteria around the root surface is due to the presence of exudates of plant roots which helps to flourish many different types bacteria which in exchange helps in plant growth promotion ${ }^{28}$. So, reports of many researchers elucidates the isolation and characterization of PGPR from rhizoplane and rhizosphere of plants $29,30,31,32,33,34$.

Walia et al., $2018^{18}$ have reported inhibitory impact of CP $(1000 \mathrm{mg} / \mathrm{L})$ on plant growth promoting bacteria (PGPB) which certainly reduce the crop yield by preventing PGPB action. Growth experiments conducted on LB media and M9MM media supplemented with different concentration of CP (RADAR $20^{\circ} \mathrm{EC}$ ) shows that O-1, 0-2 can tolerate high concentration of CP i.e. upto $5000 \mathrm{mg} / \mathrm{L}$ which is validated from similar reports of other researchers ${ }^{35,36,37,38,39}$ where they 
have reported PGPR tolerance to various pesticides upto $600 \mathrm{mg} / \mathrm{L}$. Verma et al., $2016^{40}$ have also reported CP tolerance of isolated PGPR, but low as compared to the current study.

0-2 was selected to study its growth on analytical grade of CP as it was exhibiting all the four selected plant growth promoting traits and was able to tolerate and grow at highest concentration of CP RADAR $20 \mathrm{EC}(5000 \mathrm{mg} / \mathrm{L})$ in LB agar media and minimal media.O-2 isolate showed presence of growth at all the given concentration (50 mg/L, $500 \mathrm{mg} / \mathrm{L}$ and $1000 \mathrm{mg} / \mathrm{L}$ ) of analytical grade CP supplemented in M9MM agar media. Intensity of growth of O-2 isolate was also found to be more in M9MM broth containing (50 mg/L) $\mathrm{CP}$, analytical grade as compared to M9MM broth without chlorpyrifos. The result shows that O-2 isolate may be utilizing CP as their carbon source and will help in biodegradation of CP but further biodegradation study through technique such as high performance liquid chromatography (HPLC), gas chromatography-mass spectrophotometry (GC-MS), gel permeation chromatography (GPC) is needed to be done to prove its biodegradation potential as done by many researchers in their study $41,42,26,19$.

Growth of 0-2 isolate on higher $\mathrm{pH}$ i.e. upto $\mathrm{pH} 8.0$ is supplementary and favourable factor which will help in CP degradation as found in the study of Singh et al.,2003 ${ }^{43}$ who found enhanced rate of biodegradation of $\mathrm{CP}$ in higher $\mathrm{pH}$. The capacity of 0-2 isolate to survive and grow in the presence of high concentration of the commercial and analytical grade chlorpyrifos shows that the isolate after field trials and biodegradation study may be used as promising candidates for raising the productivity of plants even in the pesticide contaminated soils.

\section{ACKNOWLEDGEMENT}

This study was supported by CSIR (09/1126(0001)/2014-EMR-1) and partly by DBTBuilder program [BT/PR9028/INF/22/193/2013] and work station provided by Central University of Jharkhand (CUJ/P/2013/PHDLS/007), Brambe (Ranchi), Jharkhand, India

\section{REFERENCES}

1. Ahemad M, Khan MS. Effect of insecticidetolerant and plant growth-promoting
Mesorhizobium on the performance of chickpea grown in insecticide stressed alluvial soils. Journal of Crop Science and Biotechnology. 2009; 12(4):217-226.

2. Chandler D, Davidson G, Grant WP, Greaves J, Tatchell GM. Microbial biopesticides for integrated crop management: an assessment of environmental and regulatory sustainability. Trends in Food Science \& Technology. 2008; 19(5):275-283.

3. Ahemad M, Malik A. Bioaccumulation of heavy metals by zinc resistant bacteria isolated from agricultural soils irrigated with wastewater. Bacteriol. J. 2011; 2:12-21.

4. Hayat R, Ali S, Amara U, Khalid R, Ahmed I. Soil beneficial bacteria and their role in plant growth promotion: a review. Annals of Microbiology. 2010; 60(4):579-598.

5. Rajkumar M, Ae N, Prasad M N Vara, Freitas H. Potential of siderophore-producing bacteria for improving heavy metal phytoextraction. Trends in biotechnology. 2010; 28(3):142-149.

6. Braud A, Jaczaquell K, Bazot, S, Lebeau T. Enhanced phytoextraction of an agricultural $\mathrm{Cr}$ and $\mathrm{Pb}$-contaminated soil by bioaugmentation with siderophore-producing bacteria. Chemosphere. 2009; 74(2):280-286.

7. Spaepen S, Vanderleyden J, Okon Y. Plant growthpromoting actions of rhizobacteria. Advances in botanical research. 2009; 51:283-320.

8. Vessey JK. Plant growth promoting rhizobacteria as biofertilizers. Plant and soil. 2003; 255(2): 571-586.

9. Van Loon LC. Plant responses to plant growthpromoting rhizobacteria, in New Perspectives and Approaches in Plant Growth-Promoting Rhizobacteria Research. Springer. 2007; 243254.

10. Madhusudhan L. Agriculture Role on Indian Economy. Business and Economics Journal. 2015; 6(4): 1.

11. Arjun KM. Indian agriculture-status, importance and role in Indian Economy. International Journal of Agriculture and Food Science Technology. 2013; 4(4):343-346.

12. Agarwal A, Prajapati R, Singh, OP, Raza SK, Thakur LK. Pesticide residue in water - a challenging task in India. Environmental monitoring and assessment. 2015;187(2):54.

13. John EM, Shaike JM. Chlorpyrifos: pollution and remediation. Environmental Chemistry Letters. 2015; 13(3):269-291.

14. Li X, Jiang J, Gu L, Ali SW, He J, Li S. Diversity of chlorpyrifos-degrading bacteria isolated from chlorpyrifos-contaminated samples. 
International Biodeterioration \& Biodegradation. 2008; 62(4):331-335.

15. Daam MA, Van den Brink PJ, Nogueira AJA. Impact of single and repeated applications of the insecticide chlorpyrifos on tropical freshwater plankton communities. Ecotoxicology. 2008; 17(8):756-771.

16. Ruan QL, Ju JJ, Li YH, Li XB, Liu R, Liang GY, Zang J, Pu YP, Wang DY, Yin LH. Chlorpyrifos exposure reduces reproductive capacity owing to a damaging effect on gametogenesis in the nematode Caenorhabditis elegans. Journal of Applied Toxicology. 2012; 32(7):527-535.

17. Pozo C, Martinez-Toledo MV, Salmeron V, Rodelas B, Gonzalez-Lopez J. Effect of chlorpyrifos on soil microbial activity. Environmental Toxicology and Chemistry: An International Journal. 1995; 14(2):187-192.

18. Walia A, Sumal K, Kumari S. Effect of Chlorpyrifos and Malathion on Soil Microbial Population and Enzyme Activity. Acta Scientific Microbiology. 2018; 1.

19. Supreeth M, Chandrashekar MA, Sachin $\mathrm{N}$, Raju NS. Effect of chlorpyrifos on soil microbial diversity and its biotransformation by Streptomyces sp. HP-11. 3 Biotech. 2016; 6(2): 147.

20. Shan $M$, Fang $H$, Wang $X$, Feng $B$, Chu $X$, Yu $Y$. Effect of chlorpyrifos on soil microbial populations and enzyme activities. Journal of Environmental Sciences-Amsterdam. 2006; 18(1):4-5.

21. Prescott LM, Harley JP, Klein DA. 2002. Microorganisms in aquatic environments In Microbiology, pp. 632-663. 5th Ed. Mc Gram-Hill Companies Inc, New York.

22. Aneja KR. 2003. Experiments in Microbiology, Plant pathology and Biotechnology. pp. 102-105. 4th Ed. New Age International (P) Ltd. New Delhi.

23. Boddey RM, Dobereiner J. Nitrogen fixation associated with grasses and cereals: recent progress and perspectives for the future, in Nitrogen Economy in Tropical Soils. Springer. 1995; 241-250.

24. Gordon SA, Weber RP. Colorimetric estimation of indoleacetic acid. Plant physiology. 1951; 26(1):192.

25. Schwyn B, Neilands JB. Universal chemical assay for the detection and determination of siderophores. Analytical biochemistry. 1987; 160(1):47-56.

26. Chen S, Liu C, Peng C, Liu H, Hu M, Zhong G. Biodegradation of chlorpyrifos and its hydrolysis product 3, 5, 6-trichloro-2-pyridinol by a new fungal strain Cladosporium cladosporioides $\mathrm{Hu}$ -
01. PloS one. 2012; 7(10):e47205.

27. Sambrook J, Russell DW. 2001. Molecular cloning: a laboratory manual, pp. A1.5. 3rd Ed. Cold Spring Harb Lab Press Cold Spring Harb, New York.

28. Badri DV, Weir TL, Van der Lelie D, Vivanco JM. Rhizosphere chemical dialogues: plant-microbe interactions. Current opinion in biotechnology. 2009: 20(6):642-650.

29. Govindarajan M, Kwon SW, Weon HY. Isolation, molecular characterization and growthpromoting activities of endophytic sugarcane diazotroph Klebsiella sp. GR9. World Journal of Microbiology and Biotechnology. 2007; 23(7):997-1006.

30. Farina R, Beneduzi A, Ambrosini A, de Campos SB, Lisboa BB, Wendisch V, Vargas LK, Passaglia LMP. Diversity of plant growth-promoting rhizobacteria communities associated with the stages of canola growth. Applied Soil Ecology. 2012; 55:44-52.

31. Islam S, Akanda AM, Prova A, Islam MT, Hossain MM. Isolation and identification of plant growth promoting rhizobacteria from cucumber rhizosphere and their effect on plant growth promotion and disease suppression. Frontiers in microbiology. 2016; 6:1360.

32. Majeed A, Abbasi MK, Hameed S, Imran A, Rahim $\mathrm{N}$. Isolation and characterization of plant growthpromoting rhizobacteria from wheat rhizosphere and their effect on plant growth promotion. Frontiers in microbiology. 2015; 6:198.

33. de Souza R, Beneduzi A, Ambrosini A, Da Costa PB, Meyer J, Vargas LK, Schoenfeld R, Passaglia LMP. The effect of plant growth-promoting rhizobacteria on the growth of rice (Oryza sativa L.) cropped in southern Brazilian fields. Plant and soil. 2013; 366(1-2):585-603.

34. Kloepper JW, Leong J, Teintze M, Schroth MN. Enhanced plant growth by siderophores produced by plant growth-promoting rhizobacteria. Nature. 1980; 286(5776):885.

35. Chennappa G, Adkar-Purushothama CR, Naik MK, Suraj U, Sreenivasa MY. Impact of pesticides on PGPR activity of Azotobacter sp. isolated from pesticide flooded paddy soils. Greener J Biol Sci. 2014; 4(4):117-129.

36. Ahmad M, Akhtar MF, Jamil M, Latif M, Ahmad I. Pesticide tolerant plant growth promoting rhizobacteria isolated from rhizosphere of okra. Soil \& Environment. 2015; 34(2).

37. Pratibha Y, Krishna SS. Plant growth promoting Rhizobacteria: An effective tool to remediate residual organophosphate pesticide methyl parathion, widely used in Indian agriculture. 
Journal of Environmental Research and Development. 2015; 9(4):1138.

38. Shahid M, Khan MS. Assessment of glyphosate and quizalofop mediated toxicity to greengram [Vigna radiata (L.) Wilczek], stress abatement and growth promotion by herbicide tolerant Bradyrhizobium and Pseudomonas species. Int J Curr Microbiol App Sci. 2017; 6(12):3001-3016.

39. Tripti, Kumar A, Kumar V, Anshumali. Effect of commercial pesticides on plant growthpromoting activities of Burkholderia sp. strain L2 isolated from rhizosphere of Lycopersicon esculentum cultivated in agricultural soil. Toxicological \& Environmental Chemistry. 2015; 97(9):1180-1189.

40. Verma JP, Jaiswal DK, Maurya PK. Screening of bacterial strains for developing effective pesticide-tolerant plant growth-promoting microbial consortia from rhizosphere soils of vegetable fields of eastern Uttar Pradesh, India. Energy, Ecology and Environment. 2016; 1(6):408-418.

41. Uygun U. Degradation of chlorfenvinphos in carrots during storage. Food chemistry. 1997; 60(4):479-487.

42. Penuela GA, Barcelo D. Application of C18 disks followed by gas chromatography techniques to degradation kinetics, stability and monitoring of endosulfan in water. Journal of chromatography A. 1998; 795(1):93-104.

43. Singh BK, Walker A, Morgan JAW, Wright DJ. Effects of soil $\mathrm{pH}$ on the biodegradation of chlorpyrifos and isolation of a chlorpyrifosdegrading bacterium. Applied and environmental microbiology. 2003; 69(9):5198-5206. 